\title{
Chemical, Microbiological, and Functional Characterization of Kefir Produced from Cow's Milk and Soy Milk
}

\author{
Raúl Ricardo Gamba, ${ }^{1}$ Shihori Yamamoto, ${ }^{1}$ Mahmoud Abdel-Hamid, ${ }^{2}$ Tetsuya Sasaki, ${ }^{3}$ \\ Toshihide Michihata, ${ }^{3}$ Takashi Koyanagi, ${ }^{1}$ and Toshiki Enomoto ${ }^{1}{ }^{1}$ \\ ${ }^{1}$ Department of Food Science, Ishikawa Prefectural University, Nonoichi, Ishikawa 921-8836, Japan \\ ${ }^{2}$ Dairy Science Department, Faculty of Agriculture, Cairo University, Giza, Egypt \\ ${ }^{3}$ Chemistry and Food Department, Industrial Research Institute of Ishikawa, Kanazawa, Ishikawa 920-0223, Japan
}

Correspondence should be addressed to Toshiki Enomoto; enomoto@ishikawa-pu.ac.jp

Received 4 November 2019; Accepted 21 April 2020; Published 12 May 2020

Academic Editor: Joseph Falkinham

Copyright (c) 2020 Raúl Ricardo Gamba et al. This is an open access article distributed under the Creative Commons Attribution License, which permits unrestricted use, distribution, and reproduction in any medium, provided the original work is properly cited.

\begin{abstract}
Kefir is a functional beverage that contains lactic and acetic acid bacteria (LAB, AAB) and yeasts. This work's aim was to study the chemical, microbial, and functional characteristics of kefir produced from cow's milk and soy milk. After fermentation, free amino acids were $20.92 \mathrm{mg} 100 \mathrm{~mL}^{-1}$ and $36.20 \mathrm{mg} 100 \mathrm{~mL}^{-1}$ for cow's milk and soy milk kefir, respectively. Glutamic acid was majority in both, suggesting that microbial proteolysis leads to an increase in free amino acids including glutamic acid. $10^{8}-10^{9} \mathrm{CFU} \mathrm{mL}^{-1}$ $\mathrm{LAB}, 10^{6}-10^{7} \mathrm{CFU} \mathrm{mL} \mathrm{mL}^{-1} \mathrm{AAB}$, and $10^{6}-10^{7} \mathrm{CFU} \mathrm{mL}^{-1}$ yeasts were counted in cow's milk kefir, whereas soy milk kefir contained greatly lower yeasts and AAB. Lactococcus lactis, Kazachstania unispora, and Saccharomyces cerevisiae were isolated as major microorganisms in both kefirs. Acetobacter orientalis only existed in cow's milk kefir. Cow's milk and soy milk showed ACE inhibitory activity, which significantly increased after fermentation. Both kefirs also exhibited antioxidant activity and bactericidal activity against Escherichia coli, Salmonella Typhimurium, and Staphylococcus aureus.
\end{abstract}

\section{Introduction}

Kefir is a fermented beverage consumed since ancient times that presents typical flavour characteristics through the presence of lactic and acetic acids, ethanol, and carbon dioxide. Several health-promoting properties have been associated with kefir consumption [1], and various properties including antitumor, antibacterial, antioxidant, antifungal, antimutagenic, and hypocholesterolaemia have been demonstrated [2-4]. The main raw material for kefir, cow's milk, is consumed worldwide, with a total production of $770 \mathrm{bn}$ litres in 2013, equivalent to USD $\$ 328 \mathrm{bn}$, as the top agricultural commodity [5]. However, for various reasons some people do not consume milk: they may be vegan or have health problems such as lactose intolerance or casein allergy. Thereby, soy milk emerges as a potential replacement in kefir fermentation. The consumption of soybeans and their derivatives provides benefits to human health due to the presence of proteins, isoflavones, oligosaccharides, and other constituents [6].

Nowadays, knowledge of natural products with different functional properties is increasing. Cardiovascular disease accounts for approximately 17 million deaths per year worldwide. Within this value, complications of hypertension cause 9.4 million deaths worldwide annually. Hypertension is responsible for at least $45 \%$ of deaths due to heart disease and $51 \%$ of deaths due to stroke [7]. Angiotensin converting enzyme (ACE) influences blood pressure by converting angiotensin I (AT-I) to AT-II, a strong vasoconstrictor. This enzyme also stimulates aldosterone in the kidneys causing liquid retention in the body, triggering an increase in blood pressure [8]. Therefore, research on foods containing ACE inhibitory compounds has become important in the hope of counteracting this public health problem. Antioxidant activity is another important food function. Although aerobic 
metabolism creates energy in the body, reactive oxygen species are also produced. These compounds are associated with several diseases such as atherosclerosis, arthritis, cancer, and hypertension [9]. Our bodies have different mechanisms to control these oxygen radicals but they are not completely effective, and intake of foods with additional antioxidants is desirable. Antibacterial activity is also gaining much attention in the field of functional food research due to the problems arising from excessive use of antibiotics. Escherichia coli and nontyphoidal Salmonella species (such as $S$. Typhimurium) along with Campylobacter species and norovirus are mainly responsible for diarrhoeal diseases [10]. Nontyphoidal salmonellae are a leading cause of bacterial diarrhoea worldwide, estimated to cause approximately 153 million cases of gastroenteritis and 57,000 deaths globally each year [11]. We previously reported the ACE inhibitory and antibacterial activities of sugary kefir made from various types of sugar solution, and demonstrated that these activities were significantly enhanced after fermentation [12]. The microbial and chemical compositions of kefir, as well as the way they change during fermentation, are important in determining the above benefits as a functional food. However, detailed published research on kefir is limited, possibly due to the nutritional and microbial diversity of kefir products influenced by multiple factors such as milk composition, origin of the grains, fermentation time and temperature, and storage conditions. The aim of this work was to study and compare the chemical composition, microbial composition, and ACE inhibitory, antioxidant, and antibacterial activities of kefirs fermented from cow's milk and soy milk, for a better understanding of underlying mechanisms and potential health benefits.

\section{Materials and Methods}

2.1. Samples and Inoculation of Kefir Grains. Kefir grains CIDCA AGK1 were kindly provided by Professor Graciela De Antoni of National University of La Plata (Argentina). The grains were preserved in sterilised skimmed milk (Meiji Holding Co., Ltd., Japan) at $-80^{\circ} \mathrm{C}$ and activated for three successive passages at $25^{\circ} \mathrm{C}$ for $24 \mathrm{~h}(10 \% \mathrm{w} / \mathrm{v})$ in skimmed milk [13]. Soy milk (Kikkoman ${ }^{\circledR}$, Tokyo, Japan) was bought at a local supermarket. Kefir grains in soy milk were grown over 40 days to ensure their ability to ferment the medium. The media were replaced three or four times a week by fresh medium. For the respective assays, activated grains were used. The grains were incubated with cow's milk or soy milk at $25^{\circ} \mathrm{C}$ for $24 \mathrm{~h}$. After fermentation, the grains were removed by filtration with a sieve of $1-\mathrm{mm}^{2}$ mesh size, and the supernatant was designated as the kefir beverage. Recovered grains were used again for the next $24 \mathrm{~h}$ fermentation period in fresh cow or soy milk, for a total of 7 fermentations (7 days). A fraction of each of the beverages was used for microbial characterization; the remaining part (designated as the cell-free supernatant (CFS)) was centrifuged, filtered through membranes of $0.22 \mu \mathrm{m}$ pore size (Sartorius ${ }^{\circledR}$, Göttingen, Germany), and stored at $-80^{\circ} \mathrm{C}$ until use.
2.2. Bacterial Strains. Escherichia coli ATCC 11775, Salmonella enterica subspecies enterica serovar Typhimurium JCM 6977, and Staphylococcus aureus ATCC 12600 were used as test microorganisms. They were activated in nutrient broth (Nissui ${ }^{\circledR}$, Tokyo, Japan) by incubation at $37^{\circ} \mathrm{C}$ for $24 \mathrm{~h}$. Pathogens were obtained from the JCM collection (Ibaraki, Japan). A 0.5 McFarland suspension of each pathogen was prepared (corresponding to $10^{8} \mathrm{CFU} \mathrm{mL}^{-1}$ ) for antibacterial assays. The strains were kept at $-80^{\circ} \mathrm{C}$.

\subsection{Determination of Wet Weight of Kefir Grains and $p H$ and} Proximate Analysis of Cow's Milk and Soy Milk Kefir. Kefir grains grown in cow's milk and soy milk were subcultured through seven successive passages in a suitable volume of medium $(10 \% \mathrm{w} / \mathrm{v})$ and incubated at $25^{\circ} \mathrm{C}$ for $24 \mathrm{~h}$ for each fermentation. Kefir grains were washed with sterile water, dried with tissue paper, and weighed on an analytical balance model A200S (Sartorius ${ }^{\circledR}$ ). The $\mathrm{pH}$ readings were made with a $\mathrm{pH}$ metre instrument Docu- $\mathrm{pH}+$ metre $^{\mathrm{TM}}$ (Sartorius $\left.{ }^{\circledR}\right)$. Water, fat, and ash content of the kefir samples were measured according to methodology recommended by the Association of Official Analytical Chemists [14]. Total nitrogen was measured by the Kjeldahl method [14] using the ACTAC 1500 Super Kjel digestion and Vapodest distillation system (ACTAC, Tokyo, Japan). Carbohydrates were calculated by subtraction.

2.4. Determination of Organic Acid Concentration. Once fermentation was complete, the CFS was evaluated for organic acid content using a Dionex ion chromatography system ICS-1500 equipped with an Ion Pac ICE-AS6 column $(9 \times 250 \mathrm{~mm})$ (Dionex, Sunnyvale, CA, USA).

2.5. Determination of Sugar Concentration. Sugar separation and quantification were carried out through high-performance anion-exchange chromatography (HPAE). Aliquots $(20 \mu \mathrm{L})$ of CFS were automatically injected into a chromatograph (Thermo Scientific ICS 3000, Dionex Canada Ltd., Oakville, Canada) with a column CarboPac PA1 $(250 \times 2 \mathrm{~mm}, 10 \mathrm{~mm}$ particle size $)$ preceded by a CarboPac PA1 guard column $(50 \times 2 \mathrm{~mm})$ with the same packing material. The machinery was equipped with a gradient pump (model SP-5) using pulsed amperometric detection (cell with disposable working gold electrode and $\mathrm{pH}-\mathrm{Ag} / \mathrm{AgCl}$ reference electrode, Dionex/Thermo Scientific). For the elution gradient, ultrapure water (eluent A), $0.25 \mathrm{~mol} / \mathrm{L}$ $\mathrm{NaOH}$ (eluent $\mathrm{B}$ ), and $1 \mathrm{~mol} / \mathrm{L}$ acetic acid (eluent $\mathrm{C}$ ) were used, at a flow rate of $0.25 \mathrm{~mL} / \mathrm{min}$ at $30^{\circ} \mathrm{C}$. The elution gradient started with $40 \%$ eluent A and $60 \%$ eluent B for $8 \mathrm{~min}$. From $8 \mathrm{~min}$ to $30 \mathrm{~min}$, the gradient elution ratio was linearly altered to reach $60 \%$ eluent B and $40 \%$ eluent C, with the sugars being separated according to their retention times. The transition of final elution conditions to original condition occurred in $1 \mathrm{~min}$. These conditions were maintained for $30 \mathrm{~min}$ to remove impurities and to stabilise the base line before applying the next sample. The polypropylene bottles containing the mobile phases were continuously 
pressurised with nitrogen gas to minimise the development and interaction with carbon dioxide from the air. External calibrations were prepared from standard solutions of glucose, fructose, sucrose, ethanol, lactose, raffinose, and stachyose to identify their respective retention times. Carbohydrate standards (Sigma-Aldrich Co., St. Louis, MO, USA) were also used to identify the different sugars on the basis of their retention times. Chromatogram analysis was carried out using Chromeleon version 5.1 software (Dionex Corporation). The sugar contents were expressed in $\mathrm{mg}$ $100 \mathrm{~mL}^{-1}$ of sample.

2.6. Determination of Concentrations of Amino Acids and Related Compounds. Cow's milk and soy milk kefir CFS were used to determine the composition of amino acids and other related compounds ( $\gamma$-aminobutyric acid (gABA) and taurine (Tau)) by amino acid analyser model L-8000 equipped with an ion exchange \#2622 SC column $(4.6 \times 60 \mathrm{~mm})$ (Hitachi, Tokyo, Japan). The eluted compounds were detected and quantified by a postcolumn ninhydrin labelling method [15].

2.7. NAD $(P) H$ Fluorescence-Based GABase Assay. The assay was modified from Passoneau and Lowry [16]. The mastermix consisted of $0.08 \mathrm{U} / \mathrm{mL}$ GABase, $5 \mathrm{mM}$ alpha-ketoglutarate, $500 \mu \mathrm{M}$ NADP, $100 \mu \mathrm{M}$ DTT, and $4 \mathrm{mM}$ EGTA in $100 \mathrm{mM}$ sodium pyrophosphate, $\mathrm{pH}$ 8.6. Aliquots $(10 \mu \mathrm{L})$ of sample were added to 96-well optical plates (Falcon 353261) followed by $90 \mu \mathrm{L}$ of mastermix. The reaction was conducted at room temperature for $1 \mathrm{~h}$ and measured in a FLUOstar Optima with a $340 \mathrm{~nm}$ excitation/450 $\mathrm{nm}$ emission filter set (gain, 2103; 10 flashes per well).

2.8. Isolation and Purification of Bacteria and Yeasts. One millilitre of each fermented product was diluted in $0.1 \%(\mathrm{w} / \mathrm{v})$ peptone water. Bacteria and yeasts were enumerated by the surface spread technique [17]. Each diluted sample $(100 \mu \mathrm{L})$ was spread in four different culture media. Lactic acid bacteria (LAB) were enumerated in MRS (De Man-Rogosa-Sharpe medium) agar (Difco ${ }^{\circledR}$, Le Pont-de-Claix, France) and GAM (Gifu Anaerobic Medium) agar (Nissui ${ }^{\circledR}$, Tokyo, Japan). Acetic acid bacteria (AAB) were enumerated in glucose, yeast extract calcium carbonate (GYC) agar (5\% glucose (Nacalai Tesque ${ }^{\circledR}$, Kyoto, Japan); $1 \%$ yeast extract (Difco); $0.5 \%$ calcium carbonate (Nacalai Tesque); $0.03 \%$ bromocresol purple (Wako, Osaka, Japan); 2\% agar (Nacalai Tesque)) with $0.01 \%$ (w/w) cycloheximide (Nacalai Tesque). Yeasts were enumerated in Potato dextrose agar (PDA) (Eiken Chemical Co., Ltd., Tochigi, Japan) agar with $0.01 \%$ (w/w) chloramphenicol (Dr. Ehrenstorfer $\mathrm{GmbH}^{\circledR}$, Augsburg, Germany). After spreading, the GYC plates were incubated at $30^{\circ} \mathrm{C}$ for $48 \mathrm{~h}$, the MRS and GAM plates were incubated in an anaerobic incubator at $30^{\circ} \mathrm{C}$ for $72 \mathrm{~h}$, and the PDA plates were incubated at $30^{\circ} \mathrm{C}$ for $48 \mathrm{~h}$. Then, the best dilution was chosen to obtain mean colony-forming units (on every plate, 30 to $300 \mathrm{CFU}$ was the best dilution), and single colonies for isolation and identification.
2.9. Identification of Bacteria and Yeasts by Sequencing the Ribosomal RNA Gene. The bacterial and yeast genomic DNA were extracted from pure cultures. Standard genetic techniques were used, essentially as described by Sambrook and Russell [18]. Hypervariable regions of the 16/28S ribosomal RNA gene (rRNA) were sequenced to identify genotypic characteristics of representative bacteria (V1-V3) and yeasts (D1/D2). The forward primer for bacteria was $7 \mathrm{~F}$ (5' - AGAGTTTGATYMTGGCTCAG-3'), and the reverse primer was $1510 \mathrm{R}\left(5^{\prime}\right.$-ACGGYTACCTTGTTACGACTT- $\left.3^{\prime}\right)$. The forward primer for yeasts was LSU-D2f $\left(5^{\prime}\right.$ GTGGTAACTTCCATCTAAAGC- $\left.3^{\prime}\right)$, and the reverse primer was LSU-D2R ( $5^{\prime}$-GGTCCGTGTTTCAAGACGG-3 ${ }^{\prime}$ ). Forward and reverse primers were provided by Thermo Fisher Scientific ${ }^{\circledR}$ Inc. (MA, USA). A total of $30 \mu \mathrm{L}$ polymerase chain reaction (PCR) mixture contained $3 \mu \mathrm{L}$ buffer solution, $2.4 \mu \mathrm{L}$ dNTPs, $1.5 \mu \mathrm{L}$ of each primer, $0.15 \mu \mathrm{L}$ Ex Taq polymerase (Takara, Shiga, Japan), $20.85 \mu \mathrm{L}$ purified water, and $0.6 \mu \mathrm{L}$ of the extracted DNA. The PCR amplification was carried out as follows: for bacteria, template DNA was denatured for $2 \mathrm{~min}$ at $96^{\circ} \mathrm{C}$, followed by 25 cycles of denaturing at $96^{\circ} \mathrm{C}$ for $15 \mathrm{~s}$, annealing at $50^{\circ} \mathrm{C}$ for $15 \mathrm{~s}$, and primer extension at $72^{\circ} \mathrm{C}$ for $1 \mathrm{~min} 30 \mathrm{~s}$; for yeasts, template DNA was denatured for $2 \mathrm{~min}$ at $96^{\circ} \mathrm{C}$, followed by 25 cycles of denaturing at $96^{\circ} \mathrm{C}$ for $15 \mathrm{~s}$, annealing at $50^{\circ} \mathrm{C}$ for $15 \mathrm{~s}$, and primer extension at $72^{\circ} \mathrm{C}$ for $40 \mathrm{~s}$. The amplification products were analysed by electrophoresis on $1.0 \%$ agarose gels before being sequenced by Eurofins Genomics Co. Ltd. (Tokyo, Japan). Each bacterial sequence datum was used as a query sequence to search for similar sequences using EzBioCloud database (https://www.ezbiocloud.net/). For yeast identification, NCBI database was used (https://www.ncbi.nlm.nih. gov/blast/). The strains identified here showed similarity higher than $99 \%$ with type strains for bacteria and similarity of at least $98 \%$ for fungal strains. Our sequences showed high similarity with the following strains: Acetobacter orientalis strain 21F-2 (accession number BAMX01000004, 99.78\%); Lactococcus lactis JCM 5805 (BALX01000047, 100\%); Lactobacillus gallinarum JCM 2011 (BALB01000057, 99.13\%); Lactobacillus kefiri LMG 9480 (AJ621553, 99.88\%); Lactobacillus nagelii DSM 13675 (AZEV01000015, 100\%); Lactobacillus plantarum JCM 1149 (NR117813.1, 99.88\%); Lactobacillus pentosus strain 124-2 (NR_029133.1, 99.88\%); Kazachstania unispora CBS398 (KY103682.1, 100\%); Pichia kudriavzevii CBS5147 (KY104577.1, 98.64\%); Galactomyces candidum (MG650611.1, 98.08\%); Geotrichum bryndzae (KP132252.1, 98\%); and Saccharomyces cerevisiae ATCC18824 (KC881067.1, 100\%). Note that L. plantarum was not distinguished from L. pentosus by $16 \mathrm{~S}$ sequencing due to being highly phylogenetically close to each other at this level.

2.10. Determination of the ACE Inhibitory Activity. ACE inhibitory activity of kefir samples was measured by ACE Kit-WST ${ }^{\circledR}$ (Dojindo Molecular Technologies, Inc., Kumamoto, Japan), according to the manufacturer's instructions [19]. As mentioned in the instructions, blank 1 (all the reagents without sample) and blank 2 (all the reagents 
without both sample and enzyme) were prepared and measured together with the samples. Additionally, negative controls of each sample (sample + all the reagents without enzyme) were also prepared and measured. ACE inhibition (\%) was calculated as follows:

$$
\text { ACE inhibition } \%=\left[\frac{\text { A blank } 1-\text { A sample }}{\text { A blank 1-A blank 2 }}\right] \times 100 \text {, }
$$

where A blank 1 is the absorbance of the positive control (without samples); A blank 2 is the absorbance of the reagent blank (without addition of enzyme mixtures); and A sample is the absorbance in the presence of kefir. Samples were tested at five concentrations to construct the standard curve for the determination of the $\mathrm{IC}_{50}$ value (concentration of inhibitor required to inhibit $50 \%$ of the ACE activity). The magnitude of $\mathrm{IC}_{50}$ was expressed as $\mu \mathrm{g} / \mathrm{mL}$. Samples were tested in triplicate.

\subsection{Measurement of Antioxidant Activity}

2.11.1. 2,2'-Azino-bis-3-ethylbenzothiazoline-6-sulfonic Acid. ABTS assay was used to determine antioxidant activity. The activity in cow's milk and soy milk kefir samples was determined spectrophotometrically at $405 \mathrm{~nm}$ following the procedure of De Gobba et al. [20]. The addition of antioxidant compounds reduces the ABTS cations, thus causing reagent decolourisation, which is measurable spectrophotometrically, depending on the antioxidant type and concentration as well as the reaction time. The ABTS values were expressed as $\mu \mathrm{molTE} / \mathrm{g}$. To determine the ABTS radical scavenging activity, a standard curve was constructed with 0-300 $\mu \mathrm{mol}$ of Trolox. Each standard and sample were tested in triplicate.

2.11.2. Oxygen Radical Absorbance Capacity (ORAC) Assay. An ORAC assay was conducted according to the method of Dávalos et al. [21] with slight modification. Briefly, $20 \mu \mathrm{L}$ of either antioxidant (Trolox) or sample and $120 \mu \mathrm{L}$ of fluorescein were placed in a well of a black 96-well microplate, and the mixture was preincubated at $37^{\circ} \mathrm{C}$ for $15 \mathrm{~min}$. Then, $60 \mu \mathrm{L}$ of AAPH (2,2' -azobis(2-amidino-propane) dihydrochloride) solution was added rapidly, using a multichannel pipet (Thermo Fisher Scientific, Waltham, MA). Finally, the plate was shaken for $30 \mathrm{~s}$, and the fluorescence was recorded using the Infinite 200 Scan Multimode Plate Reader (Tecan ${ }^{\circledR}$, Austria) every minute for $80 \mathrm{~min}$ at $37^{\circ} \mathrm{C}$. The excitation and emission wavelengths were 485 and $520 \mathrm{~nm}$, respectively. The final ORAC values were expressed as $\mu \mathrm{mol} \mathrm{TE} / \mathrm{g}$ sample. To determine the antioxidant activity, a standard curve was constructed with $0-300 \mu \mathrm{mol}$ of Trolox.

2.12. Assay for Ferrous Ion-Chelating Ability. Ferrous ionchelating ability was determined according to the method of Decker and Welch [22]. Fermented and unfermented samples were separately mixed with $0.1 \mathrm{ml}$ of a $2 \mathrm{mM}$ solution of $\mathrm{FeCl} 2$ and $0.2 \mathrm{ml}$ of $5 \mathrm{mM}$ ferrozine. The mixture was then shaken and left to stand at room temperature for
$10 \mathrm{~min}$, before the absorbance was measured at $562 \mathrm{~nm}$. To determine the chelating effects, a standard curve was constructed with EDTA at concentrations of $0-0.1 \mathrm{mg} \mathrm{mL}^{-1}$.

2.13. Measurement of Antibacterial Activity. The inhibitory activity of CFS from fermented and unfermented cow's milk and soy milk against E. coli ATCC 11775, S. Typhimurium JMC 6977, and S. aureus ATCC 12600 was tested. One millilitre of each sample was inoculated with $10 \mu \mathrm{L}$ of a 0.5 McFarland standard pathogen suspension, uniformly mixed and incubated at $37^{\circ} \mathrm{C}$ for $48 \mathrm{~h}$. Pathogen growth was detected by assessing turbidity. To determine bacteriostatic/ bactericidal activity of the samples, aliquots of $100 \mu \mathrm{L}$ of each sample were subcultured in nutrient agar (Nissui ${ }^{\circledR}$ ) dishes and counted after incubating at $37^{\circ} \mathrm{C}$ for $24 \mathrm{~h}$. Each test was performed in duplicate.

2.14. Statistical Analysis. The results of the independent assays are presented as mean \pm standard deviation. Comparisons among replicates in every group were made using the Tukey test in the Statgraphics Plus $5.1{ }^{\circledR}$ software. All the experiments were performed at least in duplicate.

\section{Results}

3.1. Chemical Analysis. Cow's milk and soy milk were fermented by kefir grains. After seven consecutive fermentations, $\mathrm{pH}$ decreased to $4.26 \pm 0.10$ (cow's milk kefir, unfermented $\mathrm{pH}$ 6.61) and $4.40 \pm 0.05$ (soy milk kefir, unfermented $\mathrm{pH}$ 6.63) (Table 1). The grains in both the kefirs increased in biomass compared to their initial weight (a 1.58- and 3.15-fold increase for cow's milk and soy milk grains, respectively). Neither ash nor water content was significantly changed by fermentation in either kefir (Table 2). Protein and fat content increased slightly in cow's milk kefir but significantly in soy milk kefir. Carbohydrate concentration decreased in both kefirs due to microbial consumption. The main sugars utilised by microbes were lactose for cow's milk kefir (decrease from 4703 to $3314 \mathrm{mg}$ $100 \mathrm{~mL}^{-1}$ during fermentation) and sucrose for soy milk kefir (from 751 to $161 \mathrm{mg} 100 \mathrm{~mL}^{-1}$ ) (Table 3). Stachyose and raffinose were maintained at significant concentrations in soy milk kefir, not being assimilated by kefir microorganisms. Sugar content was shown to have decreased more in fermented cow's milk (1.06\% and $1.36 \%$ of sugar decrease by proximate and HPAE analysis, respectively) than fermented soy milk $(0.57 \%$ and $0.54 \%$ of sugar decrease in proximate and HPAE analysis, respectively) (Tables 2 and 3).

The major organic acid was lactic acid in both fermented kefir beverages (Table 4), with values of 1307 and $698 \mathrm{mg}$ $100 \mathrm{~mL}^{-1}$ in fermented cow's milk and soy milk, respectively. The levels of other organic acids varied, with soy milk kefir containing a significantly higher concentration of citric acid (260 mg $\left.100 \mathrm{~mL}^{-1}\right)$ than cow's milk kefir $\left(109 \mathrm{mg} 100 \mathrm{~mL}^{-1}\right)$; in contrast, the acetic acid concentration was higher in cow's milk kefir $\left(135 \mathrm{mg} 100 \mathrm{~mL}^{-1}\right)$ than soy milk kefir $(52 \mathrm{mg}$ $100 \mathrm{~mL}^{-1}$ ). 
TABLE 1: Kefir grain weight and pH during seven consecutive fermentations with cow's milk and soy milk.

\begin{tabular}{lcccc}
\hline Fermentation* & & $\mathrm{pH}^{* *}$ & & \multicolumn{2}{c}{ Grain weight $(\mathrm{g})^{* * *}$} \\
& Cow's milk kefir & Soy milk kefir & Cow's milk kefir & 11.17 \\
Soy milk kefir \\
\hline 1 & 4.39 & 4.47 & 11.77 & 12.47 \\
3 & 4.25 & 4.35 & 12.84 & 15.88 \\
4 & 4.18 & 4.39 & 13.02 & 20.58 \\
5 & 4.08 & 4.36 & 13.47 & 23.91 \\
6 & 4.33 & 4.48 & 15.13 & 27.68 \\
7 & 4.27 & 4.40 & 15.76 & 31.53 \\
Average +SD & 4.33 & 4.37 & & \\
\hline
\end{tabular}

${ }^{*}$ Fermentation was carried out at $25^{\circ} \mathrm{C}$ for $24 \mathrm{~h}$ at $10 \%$ (w/v) of grain inoculum. ${ }^{* *}$ Initial pH: 6.61 (cow's milk); 6.63 (soy milk). ${ }^{* * *}$ The initial weight was $10 \mathrm{~g}$ for both grains.

TABLE 2: Proximate analysis of unfermented and fermented cow's milk and soy milk with kefir grains.

\begin{tabular}{lcccc}
\hline & Unfermented cow's milk (\%) & Fermented cow's milk (\%) & Unfermented soy milk (\%) & Fermented soy milk (\%) \\
\hline Ash & $0.75 \pm 0.02^{\mathrm{a}}$ & $0.75 \pm 0.03^{\mathrm{a}}$ & $0.44 \pm 0.04^{\mathrm{b}}$ & $0.40 \pm 0.05^{\mathrm{b}}$ \\
Proteins & $3.23 \pm 0.02^{\mathrm{a}}$ & $3.25 \pm 0.16^{\mathrm{a}}$ & $4.47 \pm 0.06^{\mathrm{b}}$ & $5.09 \pm 0.29^{\mathrm{c}}$ \\
Fat & $1.11 \pm 0.15 \mathrm{a}$ & $1.34 \pm 0.34^{\mathrm{a}}$ & $3.51 \pm 0.18^{\mathrm{b}}$ & $3.87 \pm 0.12^{\mathrm{c}}$ \\
Carbohydrates* $^{\mathrm{c}}$ & 4.79 & 3.73 & 1.21 & 0.60 \\
Water & $90.12 \pm 1.26^{\mathrm{a}}$ & $90.93 \pm 1.01^{\mathrm{a}}$ & $90.37 \pm 0.10^{\mathrm{a}}$ & $90.04 \pm 1.05^{\mathrm{a}}$ \\
\hline
\end{tabular}

Values were shown as mean \pm standard deviation except carbohydrates $\left({ }^{*}\right.$ calculated by subtraction). Different lowercase letters in rows indicate that the values are significantly different.

TABLE 3: Sugar and ethanol composition in unfermented and fermented cow's milk and soy milk with kefir grains.

\begin{tabular}{lcccc}
\hline Sugar/ethanol (mg $\left.100 \mathrm{~mL}^{-1}\right)$ & Unfermented cow's milk & Fermented cow's milk & Unfermented soy milk & Fermented soy milk \\
\hline Ethanol & $\mathrm{ND}$ & $1.92 \pm 0.36$ & $\mathrm{ND}$ & $0.37 \pm 0.02$ \\
Glucose & $8.78 \pm 7.81$ & $34.74 \pm 0.69$ & $2.38 \pm 0.05$ & $4.01 \pm 0.16$ \\
Fructose & $\mathrm{ND}$ & $\mathrm{ND}$ & $1.74 \pm 1.08$ & $2.60 \pm 2.90$ \\
Lactose & $4703.14 \pm 84.86$ & $3314.17 \pm 57.81$ & $\mathrm{ND}$ & $\mathrm{ND}$ \\
Sucrose & $\mathrm{ND}$ & $\mathrm{ND}$ & $750.88 \pm 12.87$ & $161.44 \pm 1.73$ \\
Raffinose & $\mathrm{ND}$ & $\mathrm{ND}$ & $38.44 \pm 8.14$ & $38.82 \pm 5.06$ \\
Stachyose & $\mathrm{ND}$ & $\mathrm{ND}$ & $611.08 \pm 8.01$ & $658.55 \pm 2.85$ \\
Total sugar & $4711.92 \pm 92.67$ & $3349.88 \pm 59.85$ & $1404.52 \pm 30.15$ & $865.79 \pm 12.72$ \\
\hline
\end{tabular}

ND: not detected.

TABLE 4: Organic acids in unfermented and fermented cow's milk and soy milk with kefir grains.

\begin{tabular}{lcccc}
\hline $\begin{array}{l}\text { Organic acids (mg } \\
\left.100 \mathrm{~mL}^{-1}\right)\end{array}$ & $\begin{array}{c}\text { Unfermented cow's } \\
\text { milk }\end{array}$ & $\begin{array}{c}\text { Fermented cow's milk (cow's milk } \\
\text { kefir) }\end{array}$ & $\begin{array}{c}\text { Unfermented soy } \\
\text { milk }\end{array}$ & $\begin{array}{c}\text { Fermented soy milk (soy milk } \\
\text { kefir) }\end{array}$ \\
\hline Lactic acid & $2.0 \pm 0.1$ & $1,306.5 \pm 111.9$ & $4.1 \pm 0.4$ & $697.7 \pm 15.6$ \\
Acetic acid & $20.0 \pm 1.4$ & $135.3 \pm 15.2$ & $6.2 \pm 0.7$ & $51.8 \pm 18.0$ \\
Pyruvic acid & $\mathrm{ND}$ & $4.5 \pm 7.8$ & $\mathrm{ND}$ & ND \\
Citric acid & $149.0 \pm 9.6$ & $109.3 \pm 26.6$ & $217.3 \pm 14.1$ & $260.2 \pm 22.9$ \\
\hline
\end{tabular}

ND: not detected. Seven consecutive fermentations were carried out; samples on days 1, 4, and 7 were taken; and organic acids were determined. The values shown are the mean \pm standard deviation of these three measurements.

Analysis for free amino acids showed 9.72 and $33.44 \mathrm{mg}$ $100 \mathrm{~mL}^{-1}$ in unfermented cow's milk and soy milk, respectively. These values increased to 20.92 and $36.20 \mathrm{mg} 100 \mathrm{~mL}^{-1}$ for cow's milk and soy milk kefirs after fermentation, respectively, indicating proteolysis by microorganisms (Table 5). Glutamic acid was the major amino acid in unfermented cow's milk $\left(5.90 \mathrm{mg} 100 \mathrm{~mL}^{-1}\right)$, and it remained as one of major amino acids after fermentation $\left(6.21 \mathrm{mg} 100 \mathrm{~mL}^{-1}\right)$. A significant concentration of glutamic acid was also observed for soy milk kefir $\left(16.62 \mathrm{mg} 100 \mathrm{~mL}^{-1}\right)$, making it the dominant amino acid. Proline was also detected at a high level $(5.31 \mathrm{mg}$ $100 \mathrm{~mL}^{-1}$ ) in cow's milk kefir. Interestingly, some amino acid concentrations changed differently between the two types of kefir fermentation. Arginine drastically decreased during soy milk kefir fermentation (from $12.13 \mathrm{mg} 100 \mathrm{~mL}^{-1}$ to ND), and the concentration of several amino acids (Met, Leu, and Val) decreased significantly in soy milk kefir whereas they increased during the fermentation of cow's milk kefir. Taurine increased after fermentation of both types of milk, and gABA was absent in all samples. 
TABle 5: Amino acids in unfermented and fermented cow's milk and soy milk with kefir grains.

\begin{tabular}{|c|c|c|c|c|}
\hline $\begin{array}{l}\text { Amino acids (mg } \\
\left.100 \mathrm{~mL}^{-1}\right)\end{array}$ & $\begin{array}{l}\text { Unfermented cow's } \\
\text { milk }\end{array}$ & $\begin{array}{l}\text { Fermented cow's milk (cow's } \\
\text { milk kefir) }\end{array}$ & $\begin{array}{l}\text { Unfermented soy } \\
\text { milk }\end{array}$ & $\begin{array}{c}\text { Fermented soy milk (soy milk } \\
\text { kefir) }\end{array}$ \\
\hline Asp & $0.42 \pm 0.31^{\mathrm{a}}$ & $0.03 \pm 0.01^{\mathrm{a}}$ & $1.66 \pm 0.01^{\mathrm{b}}$ & $2.72 \pm 0.16^{\mathrm{c}}$ \\
\hline Thr* & $0.16 \pm 0.02^{\mathrm{a}}$ & $1.30 \pm 0.33^{\mathbf{b}}$ & $0.20 \pm 0.02^{\mathrm{a}}$ & $0.39 \pm 0.03^{\mathrm{a}}$ \\
\hline Ser & $0.14 \pm 0.01^{\mathrm{a}}$ & $0.48 \pm 0.17^{\mathrm{a}}$ & $0.30 \pm 0.02^{\mathrm{a}}$ & $0.54 \pm 0.04^{\mathrm{a}}$ \\
\hline $\mathrm{AspNH}_{2}$ & ND & ND & $2.16 \pm 0.04^{\mathrm{a}}$ & $1.46 \pm 0.07^{\mathbf{b}}$ \\
\hline Glu & $5.90 \pm 0.01^{\mathrm{a}}$ & $6.21 \pm 0.57^{\mathrm{a}}$ & $8.81 \pm 0.03^{\mathrm{a}}$ & $16.62 \pm 2.26^{\mathbf{b}}$ \\
\hline GluNH$_{2}$ & $0.25 \pm 0.01^{\mathrm{a}}$ & ND & ND & ND \\
\hline Gly & $0.73 \pm 0.04^{\mathbf{a}}$ & $0.63 \pm 0.03^{\mathrm{a}}$ & $1.72 \pm 0.03^{\mathbf{b}}$ & $2.79 \pm 0.10^{\mathrm{c}}$ \\
\hline Ala & $0.40 \pm 0.02^{\mathbf{a}}$ & $1.04 \pm 0.13^{\mathrm{a}}$ & $2.10 \pm 0.05^{\mathbf{b}}$ & $3.42 \pm 0.22^{\mathrm{c}}$ \\
\hline $\mathrm{Val}^{* *}$ & $0.22 \pm 0.03^{\mathrm{a}}$ & $1.01 \pm 0.11^{\mathbf{b}}$ & $0.46 \pm 0.01^{\mathrm{a}}$ & $0.09 \pm 0.02^{\mathrm{a}}$ \\
\hline Cys & Traces & ND & ND & ND \\
\hline Met* & $0.02 \pm 0.00^{\mathbf{a}}$ & $0.09 \pm 0.01^{\mathrm{a}}$ & $0.30 \pm 0.02^{\mathbf{b}}$ & $0.07 \pm 0.04^{\mathrm{a}}$ \\
\hline $\mathrm{Ile}^{*}$ & $0.08 \pm 0.00^{\mathrm{a}}$ & $0.88 \pm 0.16^{\mathbf{b}}$ & $0.39 \pm 0.02^{\mathrm{a}}$ & $0.10 \pm 0.01^{\mathrm{a}}$ \\
\hline Leu* $^{*}$ & $0.12 \pm 0.01^{\mathrm{a}}$ & $1.04 \pm 0.01^{\mathbf{b}}$ & $0.53 \pm 0.05^{\mathrm{c}}$ & $0.06 \pm 0.02^{\mathrm{a}}$ \\
\hline Tyr & $0.12 \pm 0.01^{\mathbf{a}}$ & $0.53 \pm 0.10^{\mathbf{a}}$ & $0.25 \pm 0.03^{\mathrm{a}}$ & $1.17 \pm 0.11^{\mathbf{b}}$ \\
\hline $\mathrm{Phe}^{*}$ & $0.05 \pm 0.01^{\mathrm{a}}$ & $0.52 \pm 0.01^{\mathbf{b}}$ & $0.57 \pm 0.04^{\mathbf{b}}$ & $0.48 \pm 0.05^{\mathbf{b}}$ \\
\hline Trp* & ND & ND & ND & ND \\
\hline Lys* & $0.35 \pm 0.04^{\mathbf{a}}$ & $0.67 \pm 0.01^{\mathrm{a}}$ & $0.77 \pm 0.03^{\mathbf{a}}$ & $2.76 \pm 0.17^{\mathbf{b}}$ \\
\hline $\mathrm{His}^{* *}$ & $0.07 \pm 0.01^{\mathrm{a}}$ & $1.07 \pm 0.09^{\mathbf{b}}$ & $0.61 \pm 0.01^{\mathrm{c}}$ & $2.08 \pm 0.05^{\mathrm{d}}$ \\
\hline Arg & $0.38 \pm 0.02^{\mathrm{a}}$ & $0.10 \pm 0.12^{\mathrm{a}}$ & $12.13 \pm 0.11^{\mathbf{b}}$ & $\mathrm{ND}^{\mathbf{a}}$ \\
\hline Pro & $0.30 \pm 0.02^{\mathrm{a}}$ & $5.31 \pm 0.41^{\mathbf{b}}$ & $0.49 \pm 0.01^{\mathrm{a}}$ & $1.43 \pm 0.07^{\mathrm{c}}$ \\
\hline Total & $9.72 \pm 0.18$ & $20.92 \pm 2.43$ & $33.44 \pm 0.17$ & $36.20 \pm 3.41$ \\
\hline Tau & $2.59 \pm 0.08^{\mathrm{a}}$ & $3.42 \pm 0.04^{\mathbf{b}}$ & $\mathrm{ND}^{\mathrm{c}}$ & $0.19 \pm 0.04^{d}$ \\
\hline gABA & ND & ND & ND & ND \\
\hline
\end{tabular}

ND: not detected. ${ }^{*}$ Essential amino acids. ${ }^{* *}$ Essential amino acid for children. Seven consecutive fermentations were carried out; samples on days 1,4 , and 7 were taken; and amino acids were determined. The values shown are the mean \pm standard deviation of these three measurements. Different lowercase letters in the rows indicate that the values are significantly different.

3.2. Microbial Analysis. Comparable populations of LAB were detected in both types of kefir $\left(10^{8}-10^{9} \mathrm{CFU} \mathrm{mL}^{-1}\right.$ and $10^{9} \mathrm{CFU} \mathrm{mL}^{-1}$ for cow's milk and soy milk kefirs, respectively) (Table 6). However, yeasts and AAB were found to be present at lower populations in soy milk kefir $\left(10^{4} \mathrm{CFU} / \mathrm{mL}\right.$ and ND, respectively) than in cow's milk kefir $\left(10^{6}-10^{7} \mathrm{CFU} \mathrm{mL}^{-1}\right.$ and $10^{6}-10^{7} \mathrm{CFU} \mathrm{mL}^{-1}$, respectively). These differences might be due to the lower sugar concentration in soy milk $(1.40 \%)$ than in cow's milk $(4.71 \%)$, which in turn suppressed the yeast counts to 2-3 logarithmic orders lower. It is also a severe drawback in soy milk kefir that the second major sugar, stachyose, cannot be metabolised by the kefir microorganisms (Table 3). The lower ethanol concentration detected in soy milk kefir ( 0.37 versus $1.92 \mathrm{mg} 100 \mathrm{~mL}^{-1}$ in cow's milk kefir) supports the difference seen in yeast activity, which in turn determines the growth of $\mathrm{AAB}$ (Table 6). This not so large difference in ethanol concentration could be explained by higher counts of AAB in cow's milk kefir, which consume a part of ethanol. From the plate counts, LAB, yeasts, and AAB represented $93 \%-98 \%, 1 \%-4 \%$, and $1 \%-3 \%$ of the microorganisms in cow's milk kefir, respectively, while in soy milk kefir almost $100 \%$ of microorganisms were LAB.

We determined the microbial species dependent on 16/ $26 \mathrm{~S}$ rDNA sequence for representative strains of each colony morphology group (214 isolates were identified in approximately 350 isolates) (Table 6). In both kefir types, Lactococcus lactis was identified as the major LAB species $\left(10^{7}-10^{9} \mathrm{CFU} \mathrm{mL} \mathrm{m}^{-1}\right)$. As for yeasts, Kazachstania unispora, Pichia kudriavzevii, and Galactomyces candidum were detected on the first day of cow's milk kefir fermentation, but Saccharomyces cerevisiae increased to $10^{7} \mathrm{CFU} \mathrm{mL}^{-1}$ by the 4 th day. In contrast, the growth of $S$. cerevisiae in soy milk kefir was weaker $\left(\sim 10^{4} \mathrm{CFU} \mathrm{mL} \mathrm{m}^{-1}\right)$, indicating that soy milk kefir is not suitable for vigorous growth of this yeast. Similarly, an AAB species, Acetobacter orientalis, was only detectable in cow's milk kefir $\left(10^{6}-10^{7} \mathrm{CFU} \mathrm{mL}^{-1}\right)$, whereas AAB was negligible in soy milk kefir. Some minor species of LAB (Lactobacillus gallinarum, Lactobacillus kefiri, Lactobacillus nagelii, and Lactobacillus plantarum/pentosus) and yeasts (Geotrichum bryndzae) were detected, but their colony counts could not be enumerated due to their scarcity (Table 6).

3.3. Functional and Antimicrobial Analysis. ACE inhibitory activity of fermented/unfermented cow's milk and soy milk was measured (Table 7). Unfermented soy milk showed 6.36 times stronger activity than unfermented cow's milk $\left(\mathrm{IC}_{50}\right.$ of 49.50 vs. $7.78 \mu \mathrm{g} / \mathrm{mL}$ for cow's milk and soy milk, respectively). However, both cow's milk and soy milk kefirs showed improved activity, with the cow's milk kefir showing the strongest ACE inhibitory activity ( $\mathrm{IC}_{50}$ of $\left.0.81 \mu \mathrm{g} / \mathrm{mL}\right)$.

Soy milk and cow's milk showed inherent antioxidant activity by three methods but at different rates, with the stronger activity overall being in soy milk (Table 8).

Table 9 summarises the antibacterial activity of cow's milk and soy milk kefir. Unfermented cow's milk and soy milk were suitable for growth of pathogens (E. coli, S. Typhimurium, and $S$. aureus), showing viable counts 
TABLE 6: Viable counts for fermented kefir made from cow's milk and soy milk.

\begin{tabular}{|c|c|c|c|c|}
\hline Kefir & $\begin{array}{l}\text { Fermentation time } \\
(\mathrm{d})^{1}\end{array}$ & Medium & $\begin{array}{l}\text { Viable counts of respective colony } \\
\text { morphology groups (CFU mL } \mathrm{mL}^{-1} \text { ) }\end{array}$ & $\begin{array}{l}\text { Species of representative strains identified } \\
\text { dependent on } 16 \mathrm{~S} / 26 \mathrm{~S} \mathrm{rDNA}^{2}\end{array}$ \\
\hline Fermented milk & 7 & $\begin{array}{l}\text { GYC } \\
\text { MRS } \\
\text { MRS } \\
\text { GAM } \\
\text { GAM } \\
\text { PDA } \\
\text { PDA } \\
\text { PDA } \\
\text { PDA } \\
\text { GYC } \\
\text { MRS } \\
\text { MRS } \\
\text { GAM } \\
\text { PDA } \\
\text { PDA } \\
\text { PDA } \\
\text { GYC } \\
\text { MRS } \\
\text { GAM } \\
\text { PDA } \\
\text { PDA } \\
\text { PDA }\end{array}$ & $\begin{array}{c}3.11 \pm 0.14 \times 10^{6} \\
6.20 \pm 0.02 \times 10^{7} \\
-3 \\
5.10 \pm 0.12 \times 10^{7} \\
- \\
2.86 \pm 0.48 \times 10^{6} \\
2.04 \pm 0.03 \times 10^{6} \\
2.50 \pm 0.70 \times 10^{4} \\
- \\
6.50 \pm 3.53 \times 10^{7} \\
9.35 \pm 0.21 \times 10^{8} \\
- \\
8.90 \pm 0.71 \times 10^{8} \\
1.90 \pm 0.53 \times 10^{7} \\
1.91 \pm 0.04 \times 10^{6} \\
4.50 \pm 3.53 \times 10^{4} \\
4.50 \pm 2.12 \times 10^{7} \\
1.37 \pm 0.07 \times 10^{9} \\
1.55 \pm 0.17 \times 10^{9} \\
1.90 \pm 0.99 \times 10^{7} \\
1.89 \pm 0.04 \times 10^{6} \\
2.00 \pm 1.41 \times 10^{4}\end{array}$ & $\begin{array}{c}\text { Acetobacter orientalis } \\
\text { Lactococcus lactis } \\
\text { Lactobacillus gallinarum } \\
\text { Lactococcus lactis } \\
\text { Lactobacillus gallinarum } \\
\text { Kazachstania unispora } \\
\text { Pichia kudriavzevii } \\
\text { Galactomyces candidum } \\
\text { Geotrichum bryndzae } \\
\text { Acetobacter orientalis } \\
\text { Lactococcus lactis } \\
\text { Lactobacillus kefiri } \\
\text { Lactococcus lactis } \\
\text { Saccharomyces cerevisiae } \\
\text { Kazachstania unispora } \\
\text { Pichia kudriavzevii } \\
\text { Acetobacter orientalis } \\
\text { Lactococcus lactis } \\
\text { Lactococcus lactis } \\
\text { Saccharomyces cerevisiae } \\
\text { Kazachstania unispora } \\
\text { Pichia kudriavzevii }\end{array}$ \\
\hline $\begin{array}{l}\text { Fermented soy } \\
\text { milk }\end{array}$ & 4 & $\begin{array}{l}\text { GYC } \\
\text { MRS } \\
\text { GAM } \\
\text { PDA } \\
\text { GYC } \\
\text { MRS } \\
\text { GAM } \\
\text { PDA } \\
\text { PDA } \\
\text { GYC } \\
\text { MRS } \\
\text { MRS } \\
\text { GAM } \\
\text { GAM } \\
\text { GAM } \\
\text { PDA } \\
\text { PDA } \\
\end{array}$ & $\begin{array}{c}\mathrm{NC}^{4} \\
2.47 \pm 0.10 \times 10^{9} \\
2.42 \pm 0.02 \times 10^{9} \\
1.05 \pm 0.32 \times 10^{4} \\
\mathrm{NC} \\
3.15 \pm 0.78 \times 10^{9} \\
4.40 \pm 1.27 \times 10^{9} \\
1.48 \pm 0.10 \times 10^{4} \\
2.60 \pm 1.98 \times 10^{4} \\
\mathrm{NC} \\
3.25 \pm 1.34 \times 10^{9} \\
- \\
3.55 \pm 0.35 \times 10^{9} \\
- \\
- \\
2.01 \pm 0.04 \times 10^{4} \\
3.35 \pm 1.91 \times 10^{3} \\
\end{array}$ & $\begin{array}{c}\text { Lactococcus lactis } \\
\text { Lactococcus lactis } \\
\text { Kazachstania unispora } \\
\text { Lactococcus lactis } \\
\text { Lactococcus lactis } \\
\text { Kazachstania unispora } \\
\text { Saccharomyces cerevisiae } \\
\\
\text { Lactococcus lactis } \\
\text { Lactobacillus nagelii } \\
\text { Lactococcus lactis } \\
\text { Lactobacillus nagelii } \\
\text { Lactobacillus plantarum/pentosus } \\
\text { Kazachstania unispora } \\
\text { Saccharomyces cerevisiae }\end{array}$ \\
\hline
\end{tabular}

${ }^{1}$ Seven days of sequential fermentation (each step was conducted at $25^{\circ} \mathrm{C}$ for $24 \mathrm{~h}$, in total seven times) of cow's milk and soy milk. ${ }^{2}$ Microorganisms that were isolated and identified but viable counts of them were under the detection limit $\left(<3 \times 10^{3} \mathrm{CFU} \mathrm{mL}^{-1}\right) .{ }^{3} \mathrm{NC}$ : not counted nor isolated $\left({ }^{<} 10^{3} \mathrm{CFU} \mathrm{mL}{ }^{-1}\right)$.

TABLE 7: ACE inhibitory activity of unfermented and fermented cow's milk and soy milk with kefir grains.

\begin{tabular}{lc}
\hline Samples & $\mathrm{IC}_{50}(\mu \mathrm{g} / \mathrm{mL})$ \\
\hline Unfermented cow's milk & $49.50 \pm 1.58^{\mathrm{a}}$ \\
Fermented cow's milk (cow's milk kefir) & $0.81 \pm 0.08^{\mathrm{b}}$ \\
Unfermented soy milk & $7.78 \pm 0.39^{\mathrm{c}}$ \\
Fermented soy milk (soy milk kefir) & $3.55 \pm 0.11^{\mathrm{d}}$ \\
\hline
\end{tabular}

Different lowercase letters indicate that the values are significantly different.

comparable to nutrient broth $\left(>1.5 \times 10^{5} \mathrm{CFU} \mathrm{mL}^{-1}\right)$. After fermentation, cow's milk and soy milk kefirs exhibited antibacterial activity against all three pathogens. The bacterium most resistant to kefir was $S$. aureus, which tolerated $25 \%$ cow's milk kefir solution and $75 \%$ soy milk kefir solution. On the other hand, all tested samples showed bactericidal activity against $E$. coli and $S$. Typhimurium. The lower antibacterial activity of soy milk kefir against $S$. aureus could be due to the low concentration of lactic and acetic acids compared to cow's milk kefir (Table 4).

\section{Discussion}

Milk from mammals (cow, goat, sheep, buffalo, etc.) is the common raw material for kefir grains [3, 23], but the composition of $\mathrm{LAB}, \mathrm{AAB}$, and yeasts may change at the species level depending on the grain origin $[4,24]$. Growth of these microorganisms makes kefir beverages acidic, as found in this and other studies $[6,25]$ (Table 1). Significant increases in lactic and acetic acids were observed regardless of the milk type, indicating the vigorous microbial growth supported by consumption of the carbohydrates contained 
TABLE 8: Antioxidant activity of kefir produced from cow's milk and soy milk.

\begin{tabular}{lccc}
\hline & $\begin{array}{c}\text { ABTS assay } \\
(\mu \mathrm{M} \mathrm{Eq} \text { Trolox mg mL }\end{array}$ & $\begin{array}{c}\text { ORAC assay } \\
\left(\mu \mathrm{M} \mathrm{Eq} \mathrm{Trolox} \mathrm{mg} \mathrm{mL} \mathrm{mL}^{-1}\right)\end{array}$ & $\begin{array}{c}\text { Ion-chelating assay } \\
\left(\mathrm{mg} \mathrm{EDTA} \mathrm{mg} \mathrm{mL}^{-1}\right)\end{array}$ \\
\hline Unfermented cow's milk & $1033.5 \pm 8.8^{\mathrm{a}}$ & $667.4 \pm 50.5^{\mathrm{a}}$ & $0.212 \pm 0.002^{\mathrm{a}}$ \\
Fermented cow's milk (cow's milk kefir) & $1403.5 \pm 18.9^{\mathrm{b}}$ & $1412.2 \pm 31.5^{\mathrm{b}}$ & $0.060 \pm 0.023^{\mathrm{b}}$ \\
Unfermented soy milk & $1469.8 \pm 33.5^{\mathrm{b}}$ & $3111.4 \pm 607.1$ & $0.185 \pm 0.008$ \\
Fermented soy milk (soy milk kefir) & $1446.8 \pm 66.6^{\mathrm{b}}$ & $3155.7 \pm 648.2$ & $0.059 \pm 0.014^{\mathrm{b}}$ \\
\hline
\end{tabular}

Different lowercase letters in columns indicate that the values are significantly different.

TAble 9: Antibacterial activity of kefir against E. coli, S. Typhimurium, and S. aureus.

\begin{tabular}{|c|c|c|c|c|}
\hline Type of kefir & CFS conc. & 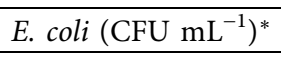 & S. Typhimurium $\left(\mathrm{CFU} \mathrm{mL} \mathrm{m}^{-1}\right)^{*}$ & S. aureus $\left(\mathrm{CFU} \mathrm{mL} \mathrm{m}^{-1}\right)^{*}$ \\
\hline \multirow{5}{*}{$\begin{array}{l}\text { Fermented cow's milk } \\
\text { (cow's milk kefir) }\end{array}$} & $100 \%$ CFS & NG $(-)$ & NG $(-)$ & NG $(-)$ \\
\hline & $75 \%$ CFS & NG $(-)$ & $\mathrm{NG}(-)$ & NG $(-)$ \\
\hline & $50 \%$ CFS & NG $(-)$ & NG (-) & NG (-) \\
\hline & $25 \%$ CFS & NG $(-)$ & NG $(-)$ & NG $\left(2.0 \times 10^{3}\right)$ \\
\hline & Unfermented CFS & $\mathrm{G}\left(>1.5 \times 10^{5}\right)$ & $\mathrm{G}\left(>1.5 \times 10^{5}\right)$ & $\mathrm{G}\left(>1.5 \times 10^{5}\right)$ \\
\hline \multirow{5}{*}{$\begin{array}{l}\text { Fermented soy milk } \\
\text { (soy milk kefir) }\end{array}$} & $100 \%$ CFS & NG $(-)$ & NG (-) & NG $(-)$ \\
\hline & $75 \%$ CFS & NG (-) & NG $(-)$ & $\mathrm{NG}\left(4.0 \times 10^{2}\right)$ \\
\hline & $50 \%$ CFS & NG $(-)$ & NG (-) & NG $\left(6.7 \times 10^{3}\right)$ \\
\hline & $25 \%$ CFS & NG $(-)$ & NG (-) & $G\left(5.3 \times 10^{4}\right)$ \\
\hline & Unfermented CFS & $\mathrm{G}\left(>1.5 \times 10^{5}\right)$ & $\mathrm{G}\left(>1.5 \times 10^{5}\right)$ & $\mathrm{G}\left(>1.5 \times 10^{5}\right)$ \\
\hline Nutrient broth & & $\mathrm{G}\left(>1.5 \times 10^{5}\right)$ & $\mathrm{G}\left(>1.5 \times 10^{5}\right)$ & $\mathrm{G}\left(>1.5 \times 10^{5}\right)$ \\
\hline
\end{tabular}

${ }^{*} \mathrm{CFSs}$ were inoculated with $3.5 \times 10^{5} \mathrm{CFU}$ of $E$. coli, $3.1 \times 10^{5} \mathrm{CFU}$ of $S$. Typhimurium, and $2.0 \times 10^{5} \mathrm{CFU}$ of S. aureus. G/NG: growth or no growth observed by turbidity. Samples were taken, inoculated, and enumerated in nutrient agar. Viable counts in nutrient agar are shown in parentheses. CFS was considered as bactericidal when no viable counts were observed.

in both cow's milk and soy milk (Table 4). The sugars most consumed were lactose for cow's milk kefir and sucrose for soy milk kefir; thus, the sugar composition could be an important factor selecting the microbes growing in each kefir beverage (Table 3). Notably, a drawback when making kefir from soy milk fermentation could be that the second major sugar, stachyose ( $44 \%$ of total sugars), is not utilised by kefir microorganisms, which might limit the microbial activity in soy milk kefir (Table 3). Our result is not in concordance with that obtained by Baú et al. [6], who reported that soy milk kefir microbes consumed raffinose and stachyose, but this difference might be due to the soy milk origin since they used laboratory-made soy milk in which sugar concentrations were considerably different. The different behaviour of citric acid levels in cow's milk and soy milk kefir (Table 4) indicated that the microbiota can influence the organic acid balance resulting in organoleptic and antimicrobial characteristics of kefirs [2, 13]. Similar results for organic acid content have been reported for cow's milk kefir [13, 25, 26] and soy milk kefir [27, 28].

The total free amino acid concentration for cow's milk kefir differs between the reports. Total free amino acids in this study were $20.92 \mathrm{mg} 100 \mathrm{~mL}^{-1}$, but three previous reports described variable concentrations from 7 to $76 \mathrm{mg}$ $100 \mathrm{~mL}^{-1}$ [29-31]. This difference could arise from a combination of factors such as proteolytic activity, assimilation, and release from the cells [32]. It has also been reported that the nutritional composition of kefir is influenced by milk type, fermentation conditions, kefir grain origin, and storage conditions [4]. The composition of major free amino acids differs between this and other studies [29-31], with the variability likely arising from the aforementioned factors. A significant concentration of Glu was detected in both cow's milk and soy milk kefir in our study, indicating that these beverages could have rich umami-related amino acid properties. Some amino acids, Arg, Met, Leu, and Val, significantly decreased during the soy milk kefir fermentation, and this might have caused the nutritional starvation that limited the microbial growth in soy milk kefir as revealed by the low yeast population and absence of AAB.

There were also variations with other amino acids. Grønnevik et al. [32] detected gABA in cow's milk kefir, levels of which increased during storage; however, we did not detect gABA in either unfermented or fermented cow's milk (measured by both amino acid analyser and enzymatic assay). On the other hand, we detected a comparable concentration of Tau ( $3.42 \mathrm{mg} 100 \mathrm{~mL}^{-1}$ in cow's milk kefir) as reported by Irigoyen et al. [30] (0.82-2.66 mg $\left.100 \mathrm{~mL}^{-1}\right)$; therefore, some kefir microorganisms were able to synthesise this amino acid (Table 5). Taurine was not detected in unfermented soy milk, but low levels were observed in soy milk kefir $\left(0.19 \mathrm{mg} 100 \mathrm{~mL}^{-1}\right)$. These results indicate that the pattern of amino acid-related compounds is sometimes robustly and sometimes variably controlled by the presence of kefir microorganisms.

Microbial contents differed greatly between cow's milk and soy milk kefirs (Table 6). Cow's milk kefir showed a typical composition of $\mathrm{LAB}, \mathrm{AAB}$, and yeasts $\left(10^{8}-10^{9} \mathrm{CFU} \mathrm{mL}^{-1} \mathrm{LAB}\right.$ and $10^{6}-10^{7} \mathrm{CFU} \mathrm{mL} \mathrm{mL}^{-1} \mathrm{AAB}$ and yeasts) whereas no $\mathrm{AAB}$ were counted in soy milk kefir $\left(10^{9} \mathrm{CFU} \mathrm{mL}^{-1} \mathrm{LAB}\right.$ and $10^{4} \mathrm{CFU} \mathrm{mL}^{-1}$ yeasts). L. lactis was the major species of LAB in both cow's milk and soy milk kefirs, and a single AAB species, A. orientalis, was identified in cow's milk kefir. As mentioned above, the available 
concentration of sugars in soy milk was low, limiting yeast growth (as seen in limited counts: $10^{3}-10^{4} \mathrm{CFU} \mathrm{mL}^{-1}$ ), which in turn meant that conditions were unsuitable for growth of $\mathrm{AAB}$ that require the ethanol produced by yeasts [33]. Despite the low yeast counts in soy milk kefir, the levels were within the limits specified for kefir [34]. Notably, the yeast species P. kudriavzevii, G. candidum, and G. bryndzae were detected only in cow's milk kefir, whereas $S$. cerevisiae and $K$. unispora were commonly found in both cow's milk and soy milk kefirs, possibly due to the different sugar concentrations available. G. bryndzae was newly identified in kefir beverage.

The results of some past reports contradict our data, especially regarding yeast populations, and the differences could derive from the setting of fermentation conditions including sugar concentration. Baú et al. [6] used laboratorymade soy milk with a high concentration of sugars, and they found $10^{6} \mathrm{CFU} \mathrm{mL} \mathrm{m}^{-1}$ yeasts, a level 100-fold higher than that in our study. Liu and Chin-Wen [25] investigated kefirs made from reconstituted skimmed milk and laboratorymade soy milk and detected slightly higher viable counts of

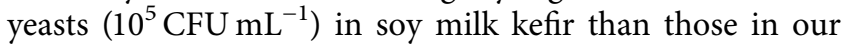
study. Dadkhah et al. [27] and Pourahmad et al. [28] used the same commercial UHT soy milk fortified with $2 \%$ sucrose (Maxsoy Company, Karaj, Iran), and both reported considerably higher yeast counts $\left(10^{8}-10^{9} \mathrm{CFU} \mathrm{mL}^{-1}\right)$. Another report, however, showed extremely low yeast counts $\left(10^{2} \mathrm{CFU} \mathrm{mL}{ }^{-1}\right)$ in both cow's milk and soy milk kefirs, indicating that the control of yeast count is sometimes casedependent and is also influenced by multiple factors other than nutrient availability, e.g., grain origin. As for LAB, it is known that the population in kefir is influenced by the starter grain LAB composition, as reported by Korsak et al. [35] who found that $\mathrm{LAB}$ and $\mathrm{AAB}$ species are grain-dependent and that the LAB contained in their fermented kefir were almost identical to those in the starter grains. One report using high-throughput $16 \mathrm{~S}$ rRNA gene pyrosequencing, on the other hand, revealed the predominance of Lactococcus in cow's milk kefir, even species initially present at low populations in the grains [24]. Although the detail is still unclear, from this and other studies, the microbiota in the kefir grains partially control those of the fermented kefir beverage, with L. lactis being one of the major facilitator LAB in cow's milk and soy milk kefir fermentation. Our analysis clearly showed that it is difficult to maintain the number of $\mathrm{AAB}$ and yeasts during the succession in soy milk kefir fermentation; therefore, it is important to always prepare new starter grains to retain the fermentation activity when soy milk kefir is industrially manufactured.

During recent years, a new public consciousness has arisen concerning the need to reduce or replace the use of antibiotics with natural products. There are many reports about the antibacterial activity of cow's milk kefir and the microorganisms contained in it $[4,13,36]$. Cow's milk kefir showed antibacterial activity against different strains of $E$. coli (including EHEC), S. aureus, Salmonella spp., Shigella sonnei, Shigella flexneri, Bacillus cereus, and Bacillus subtilis [13]. Carasi et al. [36] found that Lactobacillus kefiri isolated from kefir shows antibacterial activity against different enteropathogens. Our results agree with these, showing that fermented cow's milk and soy milk present bactericidal activity against various pathogens (Table 9). This activity could be attributable to the action of lactic and acetic acids [13] and other compounds such as bacteriocins [37].

Probiotics like kefir may change gut microbiota, triggering changes in the profile of short-chain fatty acids, such as acetate [38], that exert anti-inflammatory properties [39]. Luminal lactate promotes enterocyte proliferation and maintains the intestinal barrier [40], and citric acid has been shown to exert antioxidant activity [41]. We, too, detected antioxidant activity in cow's milk and soy milk kefir. Fiorda et al. [42] found that kefir beverages increased their radical scavenging activity from 744.3 to $960.0 \mu \mathrm{mol}$ Trolox $/ \mathrm{mL}$ to 807.1 and $1071.0 \mu \mathrm{mol}$ Trolox/mL in cow's milk-based kefir and soybean-based kefir beverages, respectively. Our results showed that antioxidant activity in cow's milk increased from 667.4 to $1033.5 \mu \mathrm{mol}$ Trolox/mL to $1403.5-1412.2 \mu \mathrm{mol}$ Trolox/mL after kefir fermentation. However, soy milk showed stronger inherent antioxidant activity than cow's milk because of the polyphenols and vitamin $\mathrm{E}$ it contained; its antioxidant activity was $1469.8-3111.4 \mu \mathrm{mol}$ Trolox $/ \mathrm{mL}$ depending on the technique, and levels did not significantly change after kefir fermentation.

It was also found that ACE inhibitory activity was significantly increased in cow's milk $(0.81 \mu \mathrm{g} / \mathrm{mL})$ and soy milk $(3.55 \mu \mathrm{g} / \mathrm{mL})$ kefirs through fermentation (Table 7). According to the World Health Organization, hypertension complications are responsible for millions of deaths every year [7], and the use of ACE inhibitors has marked a great advancement in the treatment of hypertension [43]. Quirós et al. [44] reported that one bioactive peptide obtained from goat's milk fermented with kefir grains showed a very low $\mathrm{IC}_{50}$ value of $2 \mu \mathrm{g} / \mathrm{mL}$. Fermentation by LAB could positively contribute to ACE inhibitory activity, as revealed in this study and as reported by Aihara et al. [45], who described an increase in activity following fermentation of powdered milk with $L$. helveticus. In contrast, Kwon et al. [46] reported a significant decrease in ACE inhibitory activity of soy milk kefir; thus, it would appear that ACE inhibitory activity might be affected either positively or negatively by microbial fermentation.

\section{Conclusions}

We demonstrated that kefir fermentation reduced the content of sugar contained in cow's milk and soy milk, and changed their free amino acid profile. Soy milk kefir showed less microbial diversity than cow's milk kefir, with low yeast counts and an absence of AAB. We report the yeast $G$. bryndzae in cow's milk kefir for the first time. Both cow's milk and soy milk kefir showed significant ACE inhibitory activity, a factor that may be beneficial for people with high blood pressure. Soy milk showed inherent stronger antioxidant activity regardless of the kefir fermentation, although cow's milk kefir improved its antioxidant activity compared to raw cow's milk. Antibacterial activity was proved in both beverages mainly due to high concentrations of organic acids. Soy milk kefir may be a beverage of great 
interest to vegans or people with disorders like lactose intolerance. Further studies are necessary to elucidate the compounds responsible for ACE inhibitory activity and to corroborate kefir properties in animal models.

\section{Data Availability}

All data generated or analysed during this study are included in the manuscript.

\section{Conflicts of Interest}

The authors declare that they have no conflicts of interest.

\section{Acknowledgments}

The authors thank Professor Graciela De Antoni for providing kefir grains used in this study and MEXT (Japan) for scholarship for RRG.

\section{References}

[1] C. Saloff-Coste, "Kefir. Nutritional and health benefits of yogurt and fermented milks," Danone World Newsletter, vol. 11, pp. 11-17, 1996.

[2] R. R. Gamba, C. N. Colo, M. Correa et al., "Antifungal activity against $<\mathrm{i}>$ Aspergillus parasiticus $</ \mathrm{i}>$ of supernatants from whey permeates fermented with kefir grains," Advances in Microbiology, vol. 5, no. 6, pp. 479-492, 2015.

[3] J.-R. Liu, S.-Y. Wang, M.-J. Chen, H.-L. Chen, P.-Y. Yueh, and C.-W. Lin, "Hypocholesterolaemic effects of milk-kefir and soyamilk-kefir in cholesterol-fed hamsters," British Journal of Nutrition, vol. 95, no. 5, pp. 939-946, 2006.

[4] D. D. Rosa, M. M. S. Dias, Ł. M. Grześkowiak, S. A. Reis, L. L. Conceição, and M. d. C. G. Peluzio, "Milk kefir: nutritional, microbiological and health benefits," Nutrition Research Reviews, vol. 30, no. 1, pp. 82-96, 2017.

[5] FAO (Food and Agriculture Organization of the United Nations), The Global Dairy Sector: Facts, FAO, Rome, Italy, 2016.

[6] T. R. Baú, S. Garcia, and E. I. Ida, "Changes in soymilk during fermentation with kefir culture: oligosaccharides hydrolysis and isoflavone aglycone production," International Journal of Food Sciences and Nutrition, vol. 66, no. 8, pp. 845-850, 2015.

[7] WHO (World Health Organization), A Global Brief on Hypertension, pp. 1-39, WHO, Geneva, Switzerland, 2013.

[8] Z. Ahmed, Y. Wang, A. Ahmad et al., "Kefir and health: a contemporary perspective," Critical Reviews in Food Science and Nutrition, vol. 53, no. 5, pp. 422-434, 2013.

[9] B. Halliwell and J. M. C. Gutteridge, "Oxygen toxicity, oxygen radicals, transition metals and disease," Biochemical Journal, vol. 219, no. 1, pp. 1-14, 1984.

[10] WHO (World Health Organization), The Burden of Foodborne Diseases Is Substantial, pp. 1-3, WHO, Geneva, Switzerland, 2015.

[11] J. C. Hunter and L. Watkins, "Chapter 3. Infectious diseases related to travel," CDC, Atlanta, GA, USA, 2017, https:// wwwnc.cdc.gov/travel/yellowbook/2018/infectious-diseasesrelated-to-travel/salmonellosis-nontyphoidal.

[12] R. R. Gamba, S. Yamamoto, T. Sasaki et al., "Microbiological and functional characterization of kefir grown in different sugar solutions," Food Science and Technology Research, vol. 25, no. 2, pp. 303-312, 2019.
[13] G. L. Garrote, A. G. Abraham, and G. L. De Antoni, "Inhibitory power of kefir: the role of organic acids," Journal of Food Protection, vol. 63, no. 3, pp. 364-369, 2000.

[14] AOAC, Official Methods of Analysis, Association of Official Analytical Chemists, Arlington: VA, USA, 17th edition, 2003.

[15] D. H. Spackman, W. H. Stein, and S. Moore, "Automatic recording apparatus for use in chromatography of amino acids," Analytical Chemistry, vol. 30, no. 7, pp. 1190-1206, 1958.

[16] J. V. Passoneau and O. H. Lowry, Enzymatic Analysis: A Practical Guide, Humana Press, Totowa, NJ, USA, 1993.

[17] K. T. Magalhães, de. M. G. V. Pereira, D. R. Dias, and R. F. Schwan, "Microbial communities and chemical changes during fermentation of sugary Brazilian kefir," World Journal of Microbiology and Biotechnology, vol. 26, no. 7, pp. 12411250, 2010.

[18] J. Sambrook and D. W. Russell, Molecular Cloning: A Laboratory Manual, Cold Spring Harbor Laboratory, Cold Spring Harbor, New York, NY, USA, 3rd edition, 2001.

[19] T. Hagi, M. Kobayashi, and M. Nomura, "Metabolome analysis of milk fermented by $\gamma$-aminobutyric acid-producing Lactococcus lactis," Journal of Dairy Science, vol. 99, no. 2, pp. 994-1001, 2016.

[20] C. De Gobba, F. J. Espejo-Carpio, L. H. Skibsted, and J. Otte, "Antioxidant peptides from goat milk protein fractions hydrolysed by two commercial proteases," International Dairy Journal, vol. 39, no. 1, pp. 28-40, 2014.

[21] A. Dávalos, C. Gómez-Cordovés, and B. Bartolomé, "Extending applicability of the oxygen radical absorbance capacity (ORAC-Fluorescein) assay," Journal of Agricultural and Food Chemistry, vol. 52, no. 1, pp. 48-54, 2004.

[22] E. A. Decker and B. Welch, "Role of ferritin as a lipid oxidation catalyst in muscle food," Journal of Agricultural and Food Chemistry, vol. 38, no. 3, pp. 674-677, 1990.

[23] M. Prado, L. Blandón, L. Vandenberghe et al., "Milk kefir: composition, microbial cultures, biological activities, and related products," Frontiers in Microbiology, vol. 6, p. 1177, 2015.

[24] A. J. Marsh, O. O'Sullivan, C. Hill, R. P. Ross, and P. D. Cotter, "Sequencing-based analysis of the bacterial and fungal composition of kefir grains and milks from multiple sources," PLoS One, vol. 8, Article ID e69371, 671 pages, 2013.

[25] J. Liu and L. Chin-Wen, "Production of kefir from soy milk with or without added glucose, lactose, or sucrose," Journal of Food Science, vol. 65, no. 2, pp. 716-719, 2000.

[26] C. P. Vieira, T. S. Álvares, L. S. Gomes, A. G. Torres, V. M. F. Paschoalin, and C. A. Conte, "Kefir grains change fatty acid profile of milk during fermentation and storage," PLoS One, vol. 10, Article ID e0139910, 18 pages, 2015.

[27] S. Dadkhah, R. Pourahmad, M. Mazaheri, and A. Moghimi, "Kefir production from soy milk," Annals of Biological Research, vol. 2, no. 6, pp. 293-299, 2011.

[28] R. Pourahmad, S. Dadkhah, and M. M. Assadi, "Chemical, microbiological and sensory properties of soy milk kefir during cold storage," Australian Journal of Basic and Applied Sciences, vol. 6, pp. 418-421, 2011.

[29] Z. Güler, A. Tekin, and Y. Park, "Comparison of biochemical changes in kefirs produced from organic and conventional milk at different inoculation rates of kefir grains," Journal of Food Science and Nutrition Therapy, vol. 2, no. 1, pp. 008-014, 2016.

[30] A. Irigoyen, M. Ortigosa, S. García, F. C. Ibáñez, and P. Torre, "Comparison of free amino acids and volatile components in three fermented milks," International Journal of Dairy Technology, vol. 65, no. 4, pp. 578-584, 2012. 
[31] E. Simova, Z. Simov, D. Beshkova, G. Frengova, Z. Dimitrov, and Z. Spasov, "Amino acid profiles of lactic acid bacteria, isolated from kefir grains and kefir starter made from them," International Journal of Food Microbiology, vol. 107, no. 2, pp. 112-123, 2006.

[32] H. Grønnevik, M. Falstad, and J. A. Narvhus, "Microbiological and chemical properties of Norwegian kefir during storage," International Dairy Journal, vol. 21, pp. 601-606, 2011.

[33] F. Kösebalaban and M. Özilgen, "Kinetics of wine spoilage by acetic acid bacteria," Journal of Chemical Technology \& Biotechnology, vol. 55, pp. 59-63, 1992.

[34] FAO (Food and Agriculture Organization of the United Nations), Codex Standard For Fermented Milk, Vol. 243, FAO, Rome, Italy, 2nd edition, 2003.

[35] N. Korsak, B. Taminiau, M. Leclercq et al., "Short communication: evaluation of the microbiota of kefir samples using metagenetic analysis targeting the $16 \mathrm{~S}$ and $26 \mathrm{~S}$ ribosomal DNA fragments," Journal of Dairy Science, vol. 98, no. 6, pp. 3684-3689, 2015.

[36] P. Carasi, M. Diaz, S. M. Racedo, G. De Antoni, M. C. Urdaci, and M. L. Serradell, "Safety characterization and antimicrobial properties of kefir-isolated Lactobacillus kefiri," BioMed Research International, vol. 2014, Article ID e208974, 7 pages, 2014.

[37] J. Miao, H. Guo, Y. Ou et al., "Purification and characterization of bacteriocin F1, a novel bacteriocin produced by Lactobacillus paracasei subsp. tolerans FX-6 from Tibetan kefir, a traditional fermented milk from Tibet, China," Food Control, vol. 42, pp. 48-53, 2014.

[38] O. Kanauchi, A. Andoh, and K. Mitsuyama, "Effects of the modulation of microbiota on the gastrointestinal immune system and bowel function," Journal of Agricultural and Food Chemistry, vol. 61, no. 42, pp. 9977-9983, 2013.

[39] K. M. Maslowski and C. R. MacKay, "Diet, gut microbiota and immune responses," Nature Immunology, vol. 12, no. 1, pp. 5-9, 2011.

[40] T. Okada, S. Fukuda, K. Hase et al., "Microbiota-derived lactate accelerates colon epithelial cell turnover in starvationrefed mice," Nature Communications, vol. 4, pp. 1610-1654, 2013.

[41] O. M. E. Abdel-Salam, E. R. Youness, N. A. Mohammed, S. M. Y. Morsy, E. A. Omara, and A. A. Sleem, "Citric acid effects on brain and liver oxidative stress in lipopolysaccharide-treated mice," Journal of Medicinal Food, vol. 17, no. 5, pp. 588-598, 2014.

[42] F. A. Fiorda, G. V. de Melo Pereira, V. Thomaz-Soccol, A. P. Medeiros, S. K. Rakshit, and C. R. Soccol, "Development of kefir-based probiotic beverages with DNA protection and antioxidant activities using soybean hydrolyzed extract, colostrum and honey," LWT-Food Science and Technology, vol. 68, pp. 690-697, 2016.

[43] B. J. Materson and R. A. Preston, "Angiotensin-converting enzyme inhibitors in hypertension," Archives of Internal Medicine, vol. 154, no. 5, pp. 513-523, 1994.

[44] A. Quirós, B. Hernández-Ledesma, M. Ramos, L. Amigo, and I. Recio, "Angiotensin-converting enzyme inhibitory activity of peptides derived from caprine kefir," Journal of Dairy Science, vol. 88, no. 10, pp. 3480-3487, 2005.

[45] K. Aihara, O. Kajimoto, H. Hirata, R. Takahashi, and Y. Nakamura, "Effect of powdered fermented milk withLactobacillus helveticuson subjects with high-normal blood pressure or mild hypertension," Journal of the American College of Nutrition, vol. 24, no. 4, pp. 257-265, 2005.
[46] Y.-I. Kwon, E. Apostolidis, and K. Shetty, “Anti-diabetes functionality of kefir culture-mediated fermented soymilk supplemented withRhodiolaExtracts," Food Biotechnology, vol. 20, no. 1, pp. 13-29, 2006. 